\title{
当院における上肢切断例の検討（外傷および腫瘍を除く）
}

\author{
土持 兼 信 ${ }^{*}$ 多田弘 史* 松 嵉 尚 志* 西島 毅 志*
}

\section{A Study of Amputation for the Upper Extremity (Excluding Tumor and Trauma)}

\author{
Kanenobu Tsuchimochi*, Hiroshi Tada*, Takashi Matsusaki*, and Takeshi Nishijima*
}

血液透析患者，糖尿病患者の壞疽は通常下肢に生じ，上肢に発症する例はまれである，今回，当院にお ける外傷，腫瘍を除く上肢切断例について検討した。【症例】 2002 年 1 月から 2011 年 8 月までに上肢切 断を行った 21 例を対象とした. 男性 15 例, 女性 6 例. 初回手術時の年齢は 40 88 歳 (平均 64.2 歳). 透析中が 17 例（糖尿病性腎症が 12 例），11 例はシャント側の切断であった。非透析例では糖尿病性壊疽 が 1 例，へパリン起因性血栓症が 1 例，播種性血管内凝固症候群が 1 例，シェーグレン症候群（心不全合 併）が 1 例であった。最終切断高位は手指が 13 例，手関節が 5 例，前腕が 2 例，肩関節が 1 例であった. 6 例に多数回の手術が行われた.【結語】上肢切断例の多くは血液透析例で, 特にシャント側に多く, スチー ル症候群の関与が考えられた。透析技術の進歩により透析患者の生命予後が改善し，今後，上肢切断例は 増加することが予想された。

Gangrene in patients with hemodialysis or diabetes mellitus usually occurs in the lower extremity, rarely in the upper extremity. We retrospectively reviewed amputation for upper extremity, excluding tumor and trauma. We examined 21 patients who underwent amputation for upper extremity between January 2002 and August 2011. The 21 patients consisted of 15 males and six females with an average age of 64.2 (40-88). Seventeen patients were on hemodialysis (12 patients were diabetic nephropathy), 13 of them underwent amputation for the side of shunt. Clinical characteristic of patients excluding dialysis included diabetic gangrene (1), heparin-induced thrombocytopenia (1), disseminated intravascular coagulation (1), and Sjogren syndrome (1). The last amputation level was shoulder (1), forearm (2), wrist (5), digital (13). Six patients underwent operation several times. Most cases with amputation of the upper extremity on hemodialysis, especially of the side of shunt, were affected by steal syndrome. Progress of hemodialysis technology improved prognosis. Cases of amputation of the upper extremity is increasing.

Key words : amputation (切断), upper extremity（上肢), steal syndrome (スチール症候群), gangrene (壊疽)

\section{は じめに}

近年，糖尿病患者，血液透析患者の増加に伴い壊疽 の症例が増加している。その治療は時に難渋し，保存 的治療の効果が得られず，切断を余儀なくされる症例 もある。そのほとんどは下肢切断であり，上肢が切断 にいたる例は稀である．今回，当院における外傷，腫 瘍を除く上肢切断例について検討した.

\section{対}

2002 年 1 月から 2011 年 8 月までに当院で上肢切断 を行った 21 例を対象とした。男性 15 例，女性 6 例.
初回手術時の年齢は 40 8 8 歳（平均 64.2 歳）であっ た.

\section{結果}

上肢切断例の背景としては, 血液透析例が 17 例で あった。非透析例では糖尿病性壊疽が 1 例，ヘパリン 起因性血栓症が 1 例, 播種性血管内凝固症候群が 1 例, シェーグレン症候群（心不全合併）が1例であった. 血液透析例 17 例のうち, 12 例で糖尿病の既往を認 め, 11 例はシャント側の切断であった. 下肢切断の 既往が 11 例, 下肢動脈バイパス術の既往が 5 例であっ た。最終切断高位は手指が 13 例, 手関節が 5 例, 前

* 財団法人平成紫川会社会保険小倉記念病院整形外科 Department of Orthopedics, Kokura Memorial Hospital, Fukuoka, Japan 
表 1 多数回手術の症例

多数回手術の症例は 6 例で, 全例が透析例であった. 糖尿病の合併が 4 例, シャント側の切断が 5 例であった.

\begin{tabular}{c|c|c|c|c}
\hline \hline & 症例数 & 透析例 & 糖尿病合併 & シャント側の切断 \\
\hline 2 回 & 2 & $2 / 2$ & $2 / 2$ & $1 / 2$ \\
\hline 3 回 & 1 & $1 / 1$ & $1 / 1$ & $1 / 1$ \\
\hline 5 回 & 1 & $1 / 1$ & $0 / 1$ & $1 / 1$ \\
\hline 6 回 & 1 & $1 / 1$ & $1 / 1$ & $1 / 1$ \\
\hline 7 回 & 1 & $1 / 1$ & $0 / 1$ & $1 / 1$ \\
\hline
\end{tabular}

腕が 2 例，肩関節が 1 例であった。手術件数は 40 件 で，6例に多数回（2７回）の手術が行われた。その 全例が血液透析例で, 4 例に糖尿病の合併を認めた. 6 例中 5 例がシャント側の切断であった（表 1).

\section{症例}

74 歳，男性. 現病歴：2006 年から腎硬化症による 末期腎不全の診断のため血液透析導入. 2010 年 4 月よ り四肢末梢の疼痛, 色調不良が出現. 近医で保存的加 療を行うも改善なく, 当院血管外科紹介. 両下肢はバ イパス術施行された。手指の壤疽, 疼痛のため当科紹 介となった。

既往歴：高血圧，胃癌術後．シャントは左前腕.

経過：右第 4,5 指の末梢に黒色の壊疽，右第 3 指 末梢にチアノーゼを認め, 右 $3,4,5$ 指の切断を扤こ なった（図 1). 左第 2 指にも壊死を認め，切断した。 術後左第 2 指の断端の皮膚壞死を認めたため再切断を 行った（図 2). 再切断の術後, 感染を起こし掻爬, 抗 生剂入りセメント留置を行った。感染の沈静化後にセ メント除去を抢こなった。

\section{考察}

長期透析例では，透析に伴う動脈硬化が基礎となり 四肢の壞疽が発症するといわれる，糖尿病腎症による 血液透析の場合は, 上記に加え糖尿病性神経障害や末 梢循環不全，易感染性が加わり，壊疽の頻度はさらに 高くなり重症化する症例が多い，血液透析患者の壞疽 は通常下肢に生じ，糖尿病患者でも上肢に発症する症 例はまれである。しかしシャントがある場合にはその 頻度が高まることが報告されている1. 今回の結果で も上肢切断例の多くは血液透析例で, 糖尿病の合併,
シャント側の切断が多かった．特に多数回の手術が必 要となった難治例ではすべて透析例で，6 例中 4 例に 糖尿病の合併を認め, 6 例中 5 例がシャント側の切断 であった。(表 1).

シャント末梢側の動脈血流が減少し, 虚血症状を呈 することがあり，スチール症候群と呼ばれている．春 口らは 24,068 例の血液透析患者で, スチール症候群 を発症した患者は 117 例 $(0.49 \%)$ で，危険因子は中 枢側でのシャントや人工血管，閉塞性動脈硬化症，虚 血性心疾患, 脳血管疾患であると報告した ${ }^{2}$. Morsy ら ${ }^{3)}$ は arteriovenous fistula (AVF) で 110 例中 2 例 (1.8\%), arteriovenous graft (AVG) で 299 例中 13 例 $(4.3 \%)$ の手指の虚血症状を認め, 症例の特徵と して特に末梢動脈疾患が存在し $(93.3 \%)$, 大きな危 険因子であると報告した。

当科の手術件数は 2010 年に 14 件, 2011 年が 8 月 までで 6 件と近年増加傾向にある（図 3)。透析期間 が長期になると, 動脈硬化の進行とともにシャント卜 ラブルも多くなり，シャントの中枢側への再造設や人 工血管の使用が増加する。また，高齢者では虚血性心 疾患や脳血管疾患の合併の頻度も増加する。人工透析 技術が進歩し腎不全患者の生命予後が改善された結 果, 長期透析例や高齢者の透析例が増加しているため, 今後上肢の壊疽例, 特に多数回の手術が必要となる難 治例の増加が予想される.

\section{まと め}

·上肢切断例の多くは血液透析例, 特に糖尿病性腎症 の症例であった。

・シャント側の切断が多く, スチール症候群の関与が 考えられた。 

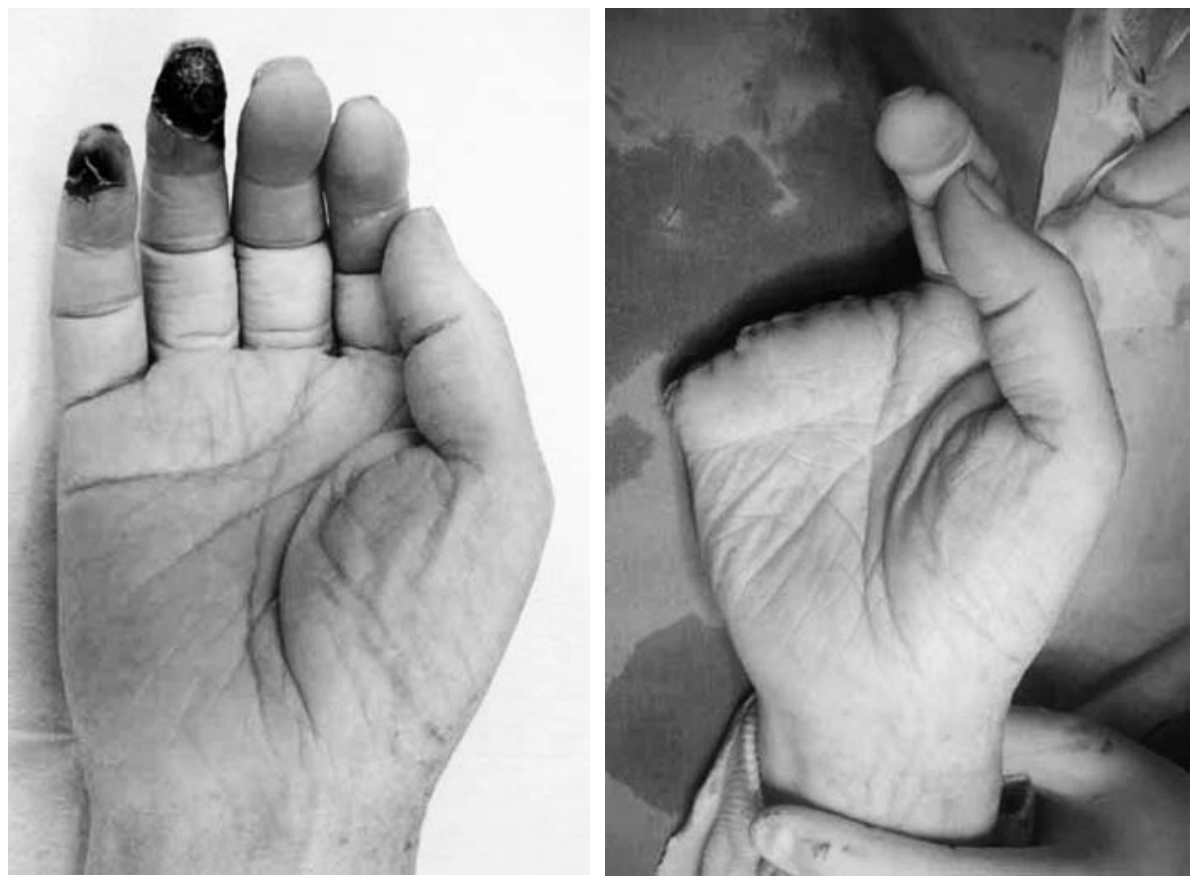

図 1 右第 4,5 指抹消に黒色の壊死，第 3 指にチアノーゼを認め, 強い疼痛の訴えを認めた（左 図). 右第 $3 ， 4,5$ 指の切断を行った (右図).
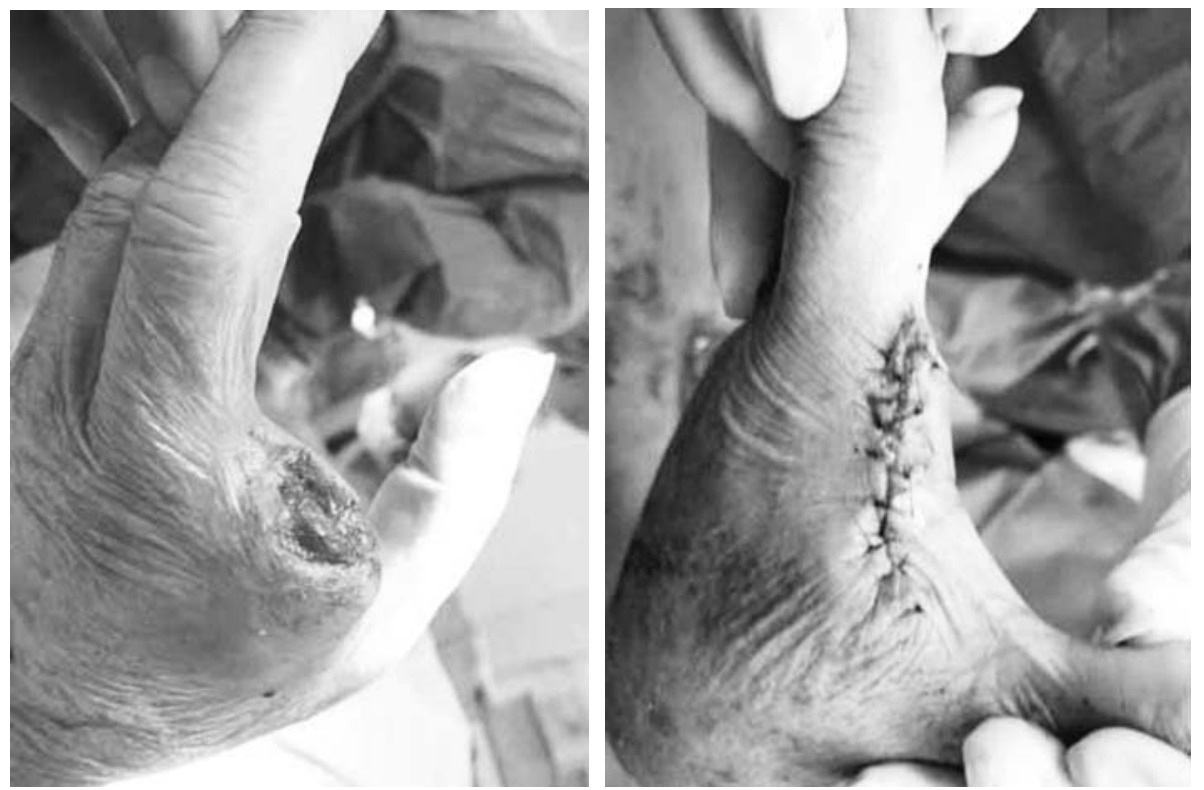

図 2 左第 2 指にも壞死を認め, 切断を行った。術後, 皮虐壞死を認めた（左図）ため再切断を行っ た (右図). 


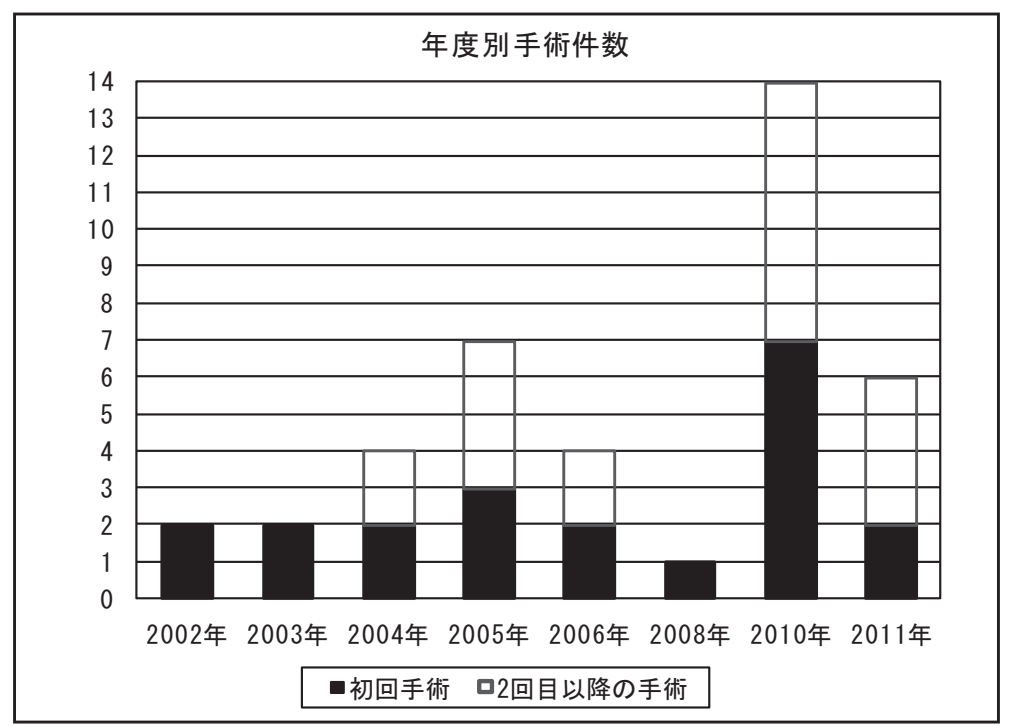

図 3 当科の手術件数は 2010 年に 14 件，2011 年が 8 月までで 6 件と近年増加傾向にある. 特に, 2 回目以降の手術件数が増加している.

・血液透析技術の進歩により, 生命予後が改善した結 果, 今後, 上肢切断例が増加することが予想される.

\section{文献}

1）鎮西伸顕，他：シャント側の前腕壊死を生じ切断にい たった糖尿病性壊疽の 1 例。整形外科，61(11)：1197-
1199, 2010.

2）春口洋昭, 他 : Steal 症候群と ischemic monomeric neuropathy. 腎と透析, 50（別冊アクセス 2001）：4047, 2001.

3) Morsy, A.H., et al. : Incidence and characteristics of patient with hand ischemia after a hemodialysis access procedure. J. Surg. Res., 74:8-10, 1998. 